\title{
POLYCYTHAEMIA AND HEPATITIS IN A NEWBORN
}

\author{
BY \\ R. J. WALSH, R. D. K. REYE and THOMAS STAPLETON \\ From the New South Wales Red Cross Blood Transfusion Service, Institute of Pathology, \\ Royal Alexandra Hospital for Children, and the Department of Child Health, University of Sydney
}

(RECEIVED FOR PUBLICATION MARCH 28, 1962)

This is a report of neonatal polycythaemia due to materno-foetal transfusion complicated by liver damage. A speculative explanation is advanced, linking these two findings, in the hope that it will lead to particular investigations of future cases of polycythaemia and hepatitis in the newborn.

\section{Case Report}

The patient was the product of the third pregnancy of a 31-year-old mother. The previous two children were girls, now aged $4 \frac{1}{2}$ and $2 \frac{1}{2}$ years, who were healthy at birth but were said to be slightly jaundiced between the second and ninth days of life. Apart from two attacks of coryza during pregnancy the mother had been well. There was some uncertainty about the expected date of delivery and, because labour was believed to be three weeks overdue, it was induced by stripping the membranes and by an intramuscular injection of 'syntocin.' Delivery on April 6, 1961, was normal and the infant cried immediately. Birth weight $7 \mathrm{lb} .12 \mathrm{oz}$.

At 36 hours of age vomiting commenced, but was not persistent.

On the eighth day of life the infant weighed $6 \mathrm{lb} .13 \mathrm{oz}$. and she was admitted to a Tresillian Home.

On the eleventh day of life it was noted that there were haemorrhages into the anterior chambers of both eyes. The baby was transferred to the Royal Alexandra Hospital for Children.

On examination, the baby weighed $6 \mathrm{lb}$. $10 \mathrm{oz}$. She was slightly cyanosed and appeared to have a high colour. There were bilateral hyphaema. She was jaundiced and the liver was palpable $2 \frac{1}{2} \mathrm{~cm}$. below the costal margin. Hydration appeared normal.

A blood count gave the following results: Red blood cells, 7,500,000/c.mm.; haemoglobin, $27 \mathrm{~g} . / 100 \mathrm{ml}$; haematocrit, $69 \%$; white blood cells, 15,000/c.mm. (neutrophils 6,000 , lymphocytes 8,000 , monocytes 1,000 ); platelets, 320,000/c.mm.

The calculated indices were: mean corpuscular volume 125 c. $\mu$; mean corpuscular haemoglobin $32 \cdot 5 \mu \mu \mathrm{g}$.; mean corpuscular haemoglobin concentration $35 \%$. Heinz bodies were not detected. The serum bilirubin was $10 \mathrm{mg} . / 100 \mathrm{ml}$. serum, of which only $2 \mathrm{mg}$. was in the conjugated state. No abnormal pigments were found on spectroscopic examination of the serum. The urine contained numerous granular casts, 15 to 20 white blood cells per high power field, and an occasional red cell, but no organisms or inclusion bodies were seen. Galactose, bile pigments and urobilinogen were not present in the urine. Radiograph of the chest did not disclose any abnormality. An electrocardiogram showed right ventricular preponderance with some changes in the T-waves.

On the thirteenth day of life abdominal distension became marked, and the infant became lethargic. The serum sodium was $120 \mathrm{mEq} / \mathrm{l}$., serum protein $5.7 \mathrm{~g} . /$ $100 \mathrm{ml}$. and blood urea $20 \mathrm{mg} . / 100 \mathrm{ml}$.

On the fourteenth day the serum sodium was 114 $\mathrm{mEq} / \mathrm{l}$., serum potassium $3.5 \mathrm{mEq} / 1$, , serum chloride $88 \mathrm{mEq} / \mathrm{l}$., serum protein $4.9 \mathrm{~g} . / 100 \mathrm{ml}$. and serum bilirubin $15 \cdot 2 \mathrm{mg} . / 100 \mathrm{ml}$. of which $5 \cdot 2$ was conjugated.

During the terminal 24 hours of life, tetracycline $10 \mathrm{mg}$./ $\mathrm{kg}$. was given intravenously; $1 \mathrm{mg}$. vitamin $\mathrm{K}$ and $10 \mathrm{ml}$. whole blood were also given intravenously.

The child died on the fourteenth day with massive gastro-intestinal haemorrhages.

Blood Grouping Tests. Blood grouping tests were performed on both mother and infant on the thirteenth day. Nearly all the mother's cells in a drop of suspension were agglutinated by anti-A serum of high titre, by anti- $\mathrm{A}_{1}$ and by an extract of the seeds of Dicholis bifloris (anti- $\mathrm{A}_{1}$ phytagglutinin). When these same reagents were mixed with drops of a suspension of the infant's red cells, mixtures of agglutinated and many unagglutinated red cells were produced. When the mixtures were examined with the microscope the number of unagglutinated cells in any field appeared to equal or exceed the number of agglutinated cells. Accurate counts were not performed as the significance of the finding was not appreciated at the time. Neither the mother's nor the infant's cells were agglutinated by anti-B serum.

In the MN tests (Ortho Pharmaceutical Company reagents) the mother's cells were strongly agglutinated by anti-M, but not at all by anti-N, so that her genotype was MM. The anti-M serum produced similar strong agglutination of the infant's cells, but anti-N serum produced a mixed field of agglutinated and unagglutinated cells. A similar mixture was obtained with anti-S serum. Red cells from the mother were all agglutinated, but only some of the red cells from the infant. In the Rh tests both the mother's and the infant's red cells were agglutinated by anti-D, anti-C and anti-c, but not by anti-E. Agglutination of the red cells by the three antibodies was nearly complete in all instances. 


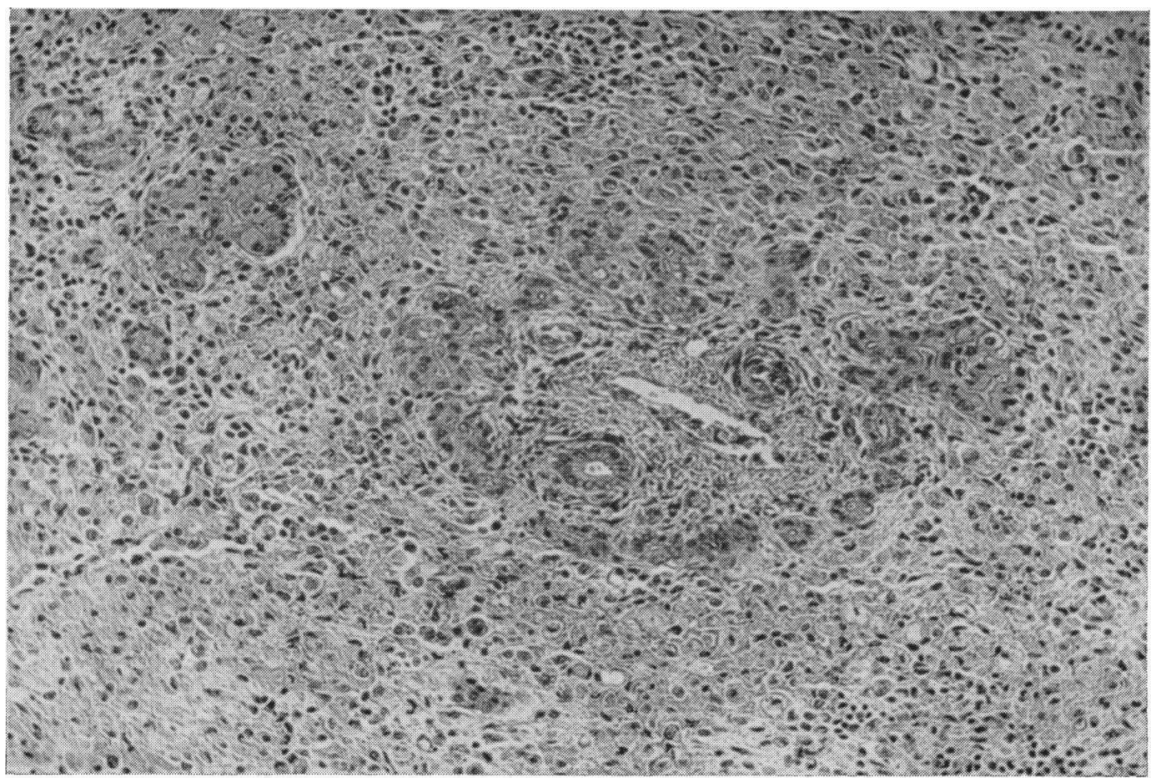

FIG. 1.-Columns of regenerating epithelium radiating from a portal tract and surrounded by necrotic parenchyma. (H. and E. $\times 125$.)

The mother's serum contained no atypical agglutinins against red cells.

Autopsy Findings. The liver on inspection was uniformly dark red except for some scattered, small, irregular, orange-coloured foci which were visible through the capsule and which extended inwards from the capsule for only a short distance. The histological pattern was that of a uniform, massive necrosis of the parenchyma with early regeneration about the portal tracts (Fig. 1); with the exception that, in the orangecoloured foci, the architecture was retained (Fig. 2). In

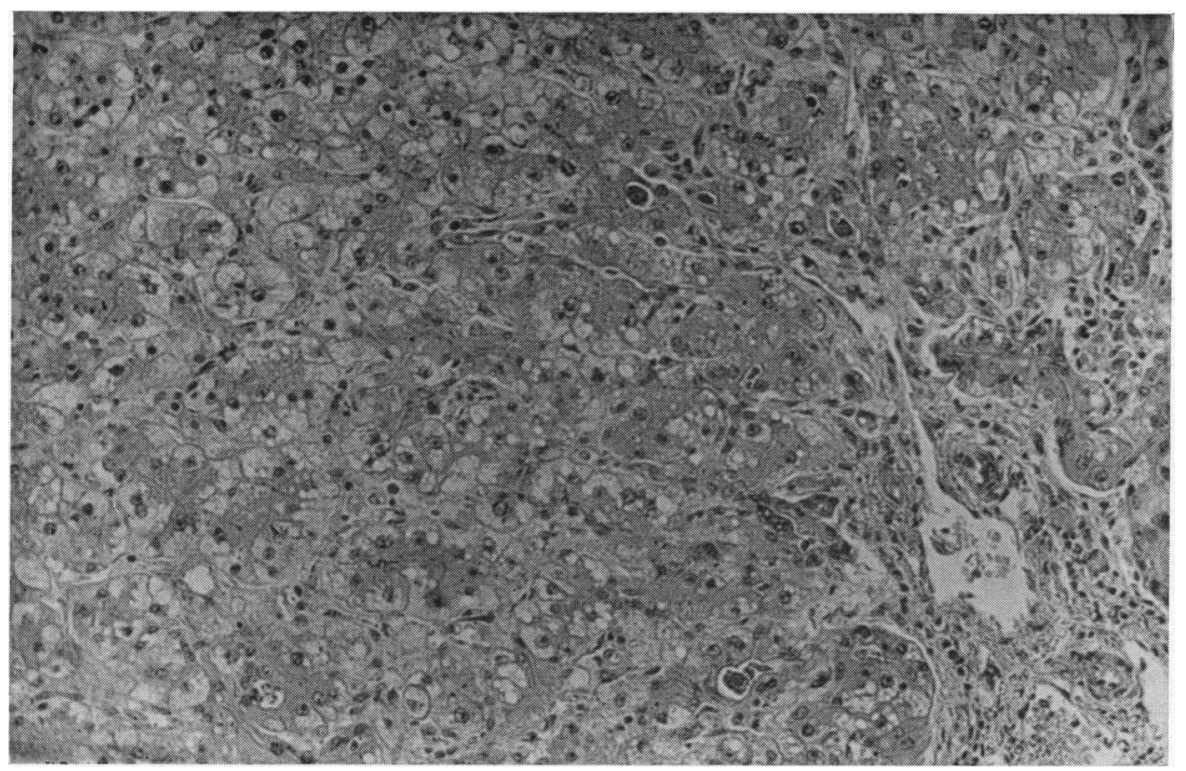

FIG. 2.-Subcapsular focus. Cellular degeneration with scattered necrotic cells. Architecture retained. (H. and E. $\times 125$.) 


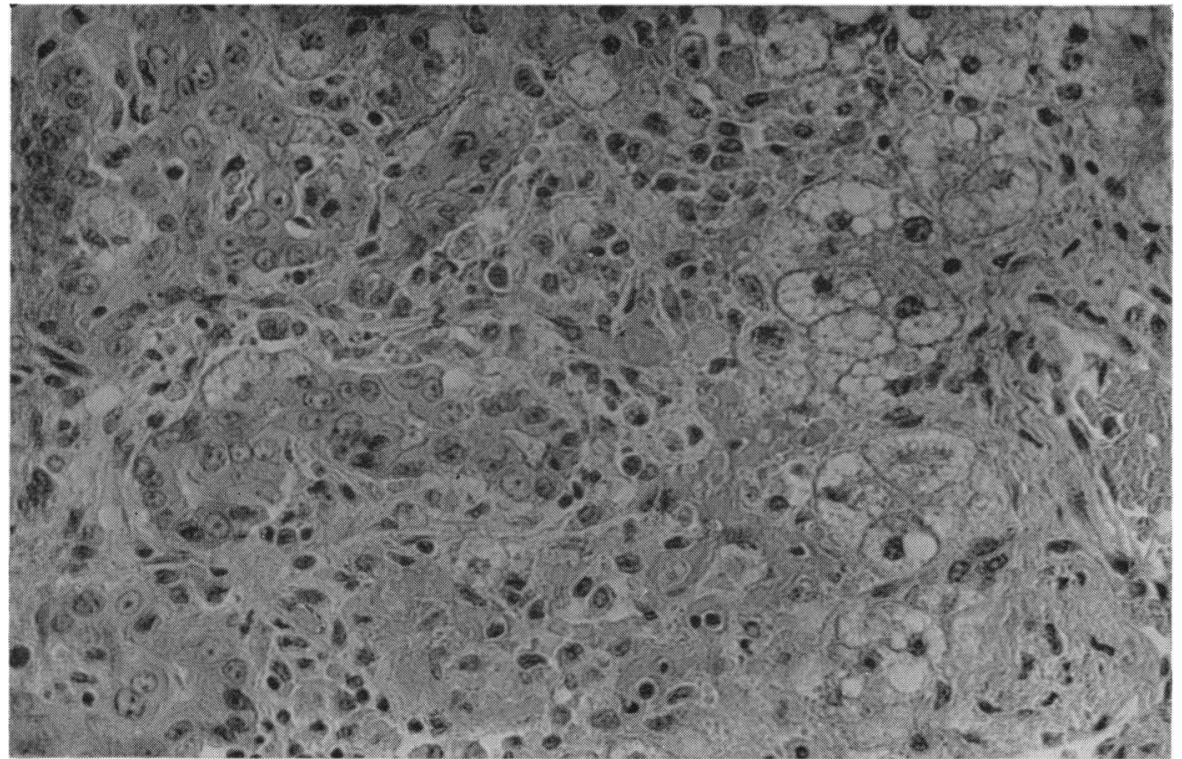

Fig. 3.-Transition zone. Foamy liver cells at right around the central vein. Columns of regenerating cells at left. (H. and E. $\times 250$.)

these foci the liver cells were swollen and the cell bodies occupied by fine, lipoid droplets. The canaliculi were distended with bile and the sinusoids compressed. No cellular infiltration had occurred in these degenerate areas, though an occasional cell, which had reached the necrotic stage, was being ingested by polymorphonuclear leucocytes. In some regions these degenerate areas abutted upon totally necrosed tissue; in others a transition zone existed in which the central part of the lobule was composed of greatly swollen, lipoid-laden and bilestained hepatic cells (Fig. 3), though the remainder of the lobule was necrosed. In the totally necrosed lobules an occasional distended, foamy, parenchymal cell could at times be found. These lobules were composed of numerous macrophages and less numerous neutrophil and eosinophil polymorphs which, together with cellular debris, occupied the spaces between the distended and blood-filled sinusoids. No plasma cells could be recognized and no unequivocal haemopoietic cells could be distinguished either in the necrosed lobules or in the portal tracts, which contained a fair complement of lymphocytes in addition to eosinophil polymorphs and macrophages. Haemosiderin was present in some excess in the degenerate cells in the subcapsular foci and in the Kupffer cells in these same areas. This pigment was abundant in the necrotic lobules, principally contained there by the macrophages, but also occurring as free granules in the debris. Haemosiderin was absent from the double columns of regenerating parenchyma adjacent to the portal tracts.

There was a small subepicranial haemorrhage over the right parietal region. The lungs showed congestive changes. The heart was normal. The ductus was patent. The pancreas was normal apart from one lobule which was scarred and heavily infiltrated with lymphocytes. The kidneys showed marked medullary congestion. The intestines were congested and contained a large quantity of blood.

There was haemorrhage into the ciliary body and iris on each side with free blood in the anterior chamber.

\section{Discussion}

Materno-foetal Transfusion. The blood grouping tests suggest that the infant's blood contained a large number of maternal red cells. The antisera used have been found to give almost complete agglutination of red cells containing the corresponding antigens from other newborn infants. The true blood groups were probably: Mother, $\mathrm{A}_{1} \mathbf{M M ~ S +}$ CcDee; infant, O MN S- CcDee.

Evidence for the occurrence of a mother-to-foetus transfusion depends on the finding in the infant of $A_{1}$ cells, of cells which did not react with anti-N and of S-positive cells. It was fortunate that the blood groups of the mother and infant differed as much as they did and that three antibodies gave consistent results. It would not have been justifiable to draw conclusions from the reactions with only one antibody.

Evidence is accumulating that foetus-to-mother transfusions are not uncommon, and a variety of techniques has been employed to demonstrate the presence of foetal cells in the maternal circulation (Chown, 1954; Dunsford, 1957; Colebatch, Pitt and Maddison, 1956; Weiner, Child, Garvie and Peek, 
1958; Zipursky, Hull, White and Israels, 1959; Apley, Colley and Fraser, 1961).

Consideration of the anatomical relation between the placental and uterine blood systems does not invalidate the possibility of a mother-to-foetus transfusion. In the present instance, separation of the membranes might have caused damage to a portion of the placenta and its uterine attachments. Subsequent to our studies on this patient, Michael and Mauer (1961) have reported three infants in whom a materno-foetal transfusion was believed to be the cause of plethora.

Neonatal Hepatitis. The histological appearance of the liver is similar to that reported in other instances of neonatal hepatitis (Dible, Hunt, Pugh, Steingold and Wood, 1954; Emery, 1955). In this case, however, the alterations in the damaged, but not yet necrotic, areas, and in the transition zones between the two, leave the impression that the progression of cellular damage is different both in degree and situation within the lobules from that which could be expected in the recognized forms of viral hepatitis. There was no history of maternal infection suggestive of hepatitis during the pregnancy, but this is usual in neonatal hepatitis. There is no reason to suppose that hepatitis could be the cause of polycythaemia of the degree found on the 11th day of life. This raises the question whether there was an association between the two conditions and whether the maternal transfusion may have been responsible for the liver necrosis. The possibility is unlikely to have been considered if the polycythaemia had not been noted, but it is probable that the sequence of events to be suggested could occur without recognizable polycythaemia.

There is no direct evidence to support the following immunological hypothesis. It is advanced in the hope that further examples of "neonatal hepatitis' will be investigated specifically to prove or disprove the theory. The hypothesis is that the mother was immunized by nuclear antigens from the foetus during pregnancy, that the immunity was transferred to the foetus by white blood cells at the time of the maternal transfusion, and that an immunological reaction similar to the homograft reaction in skin grafts, or to the graft versus host reaction in animals rendered tolerant to bone marrow grafts, was responsible for the liver necrosis.

Nuclear antigens (transplantation antigens) would pass to the mother from the foetus if leucocytes passed the placenta. Medawar (1946) showed that the transplantation antigen is present in leucocytes, as prior injection of leucocytes from a donor animal resulted in accelerated rejection of a primary skin

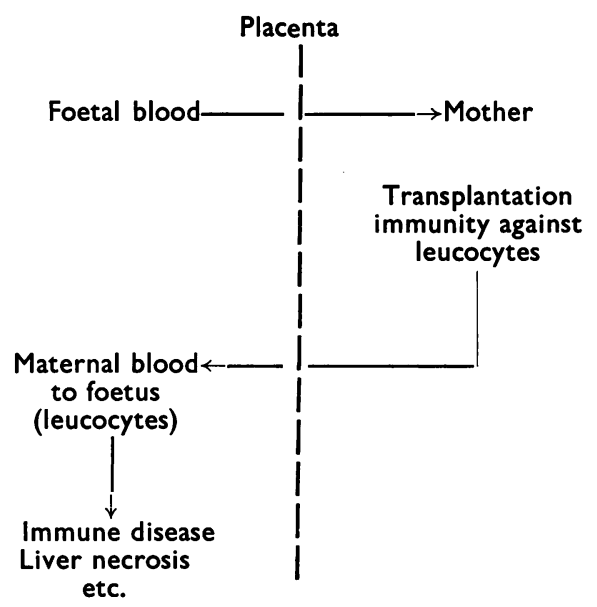

graft from the same animal. Red cells not infrequently pass to the mother, resulting in immunization against blood group antigens, but they would not produce transplantation immunity (Medawar, 1946). The simultaneous passage of leucocytes is probable, but has not been proved.

Maternal immunization against transplantation antigens is difficult to demonstrate with the techniques available at present. If this type of immunization occurred during pregnancy it might be expected that primary grafts of the infant's skin would be rapidly rejected by the mother. Grafting the skin from infants to mothers is not a practical diagnostic procedure, although it has been performed by Peer (1957) and Peer and Walker (1959). Indirect evidence of this type of immunization in mothers would be obtained if circulating antibodies against nuclear components of the infant (such as DNA) could be demonstrated by complement-fixation tests. It has been shown that such circulating antibodies are often an accompaniment of homograft immunity, but they appear to play little if any part in the homograft rejection (Billingham and Brent, 1956).

Maternal immunization would not be of clinical importance unless intact sensitized lymphocytes passed from the mother to the foetus in utero. Viable maternal lymphocytes would have been present in the infant as a result of the maternofoetal transfusion, but they may not have been capable of transferring homograft immunity. Billingham, Brent and Medawar (1954) showed that cells from lymph nodes are capable of transferring immunity, but transfer has not been demonstrated using concentrated peripheral blood lymphocytes (Lawrence, 1959).

An alternative hypothesis is that preliminary immunization of the mother by foetal antigens 
did not occur and that the tissue damage resulted from the transfer to the infant of unsensitized maternal leucocytes. If these leucocytes became established as a graft in the infant, they might have produced a graft versus host immunity reaction after transfer. This implies some degree of tolerance in the infant to the maternal antigens of the leucocytes, because grafting of leucocytes does not occur after transfusion, even exchange transfusions, in infants. The rapid onset of symptoms in this infant is more compatible with the action of leucocytes which were sensitized at the time of transfer than of leucocytes which became sensitized after transfer.

This infant had severe liver damage. Non-fatal examples may occur in other instances without the massive transfer of maternal blood, and it will be of some interest in future to examine the blood groups, either pre- or post mortem, when neonatal jaundice is unexplained. The hypothesis which has been advanced in this paper has not been proved. The hepatitis may have been of viral or other origin and unrelated to the polycythaemia due to maternofoetal transfusion.

\section{Summary}

An infant with polycythaemia due to a maternofoetal transfusion is described. Hepatitis was also present, and a speculative explanation is advanced for the association between the materno-foetal transfusion and the hepatitis.

We would like to thank Dr. W. E. Wells and Dr. B. Dowd, who referred the patient.

\section{REFERENCES}

Apley, J., Colley, P. A. N. and Fraser, I. D. (1961). Foetal haemorrhage into the maternal circulation. Lancet, 1, 1375.

Billingham, R. E. and Brent, L. (1956). Further attempts to transfer transplantation immunity by means of serum. Brit. J. exp. Path. 37, 566.

, - and Medawar, P. B. (1954). Quantitative studies on tissue transplantation immunity. Proc. roy. Soc. B, 143, 58.

Chown B. (1954) Anaemia from bleeding of the foetus into the mother's circulation. Lancet, 1, 1213.

Colebatch, J. H., Pitt, D. and Maddison, T. G. (1956). Foetomaternal transfusion: Another cause of post-haemorrhagic anaemia in the newborn. Med. J. Aust., 2, 209.

Dible, J. H., Hunt, W. E., Pugh, V. W., Steingold, L. and Wood, J. H. F. (1954). Foetal and neonatal hepatitis and its sequelae. J. Path. Bact., 67, 195.

Dunsford I. (1957). Proof of foetal antigens entering the maternal circulation. Vox. Sang. (Basel), 2, 125.

Emery, J. L. (1955). Asymmetrical liver disease in infancy. J. Path. Bact., 69, 219.

Lawrence, H. S. (1959). Homograft sensitivity: An expression of the immunologic origins and consequences of individuality. Physiol. Rev., 39, 811 .

Medawar P. B (1946). Immunity to homologous grafted skin relationship between antigens of blood and skin Brit. $J$. exp. Path., 27, 15.

Michael, A. F. and Mauer, A. M. (1961). Maternal-fetal transfusion as a cause of plethora in the neonatal period. Pediatrics, 28, 458

Peer, L. A. (1957). Behavior of skin grafts interchanged between parents and infants. Transplant. Bull., 4, 109.

- and Walker, J. C. (1959). The behaviour of skin grafts exchanged between parents and offspring. Surg. Forum, 9,781 .

Weiner, W., Child, R. M., Garvie, J. M. and Peek, W. H. (1958). Foetal cells in the maternal circulation during pregnancy. Brit. med. J., 2, 770.

Zipursky, A., Hull, A., White, F. D. and Israels, L. G. (1959). Foetal erythrocytes in the maternal circulation. Lancet. $1,451$. 